\title{
Potential-Type Sulfur Dioxide Planar Gas Sensor for High Temperature Application
}

\author{
Izu, Noriya ${ }^{1,2}$; Hagen, Gunter ${ }^{1}$; Schönauer, Daniela ${ }^{1}$; Röder-Roith, Ulla ${ }^{1}$; Moos, Ralf ${ }^{1}$ \\ ${ }^{1}$ Functional Materials, University of Bayreuth, ${ }^{2}$ National Institute of Advanced Industrial Science and \\ Technology (AIST) \\ ${ }^{1}$ Universitätsstraße 30, 95440 Bayreuth, Germany, ${ }^{2}$ Moriyama-ku, Nagoya, 463-8560 Japan
}

\begin{abstract}
For high temperature applications, planar $\mathrm{SO}_{2}$ gas sensors using Nasicon as an electrolyte and $\mathrm{V}_{2} \mathrm{O}_{5} / \mathrm{WO}_{3} / \mathrm{TiO}_{2}+\mathrm{Au}$ as sensing electrode were fabricated and investigated. The sensors show a promising response at $600{ }^{\circ} \mathrm{C}$ with a sensitivity of $80-83 \mathrm{mV} /$ decade in the $\mathrm{SO}_{2}$ range from 20 to $200 \mathrm{ppm}$. The sensors show a good selectivity. Future work has to deal with an offset drift as it has been observed in repeated measurements.
\end{abstract}

\section{INTRODUCTION}

Today, coal is a very important fuel. Besides renewable energies, it will continue to play an important role through the 21st century [1]. The identified coal reserves are expected to last for 150 years, in contrast to oil and natural gas reserves which may last for only 41 and 65 years, respectively. The cost of coal is about $1 / 6$ that of oil and natural gas. Therefore, it is predicted that coal consumption will increase by $2.5 \%$ per year in the range of 2003 to 2030 [1]. Coal, however, faces significant environmental challenges, since exhaust gas from coal combustion contains limited emissions such as $\mathrm{SO}_{2}, \mathrm{NO}_{x}$, etc. [1]. For example, the exhaust gas from coal-fired kilns includes $300-500 \mathrm{ppm}$ of $\mathrm{SO}_{2}$, or flue gases and stack gas include $500-4000 \mathrm{ppm}$ and $5-10 \%$ of $\mathrm{SO}_{2}$, respectively [2].

Thus, $\mathrm{SO}_{2}$ sensors featuring a good durability in high $\mathrm{SO}_{2}$ concentrations and at high temperatures are needed for $\mathrm{SO}_{2}$ monitoring and control. Such $\mathrm{SO}_{2}$ sensors have to be made of a very stable material. For that reason, we focused on sensors based on $\mathrm{V}_{2} \mathrm{O}_{5} / \mathrm{WO}_{3} / \mathrm{TiO}_{2}$ (abbreviated VWT), because VWT is a well-known material for ammonia selective $\mathrm{NOx}$ catalytic reduction catalysts $\left(\mathrm{NH}_{3}-\mathrm{SCR}\right)$ [3-5] applied for instance for $\mathrm{NO}_{x}$ removal in coal power plants or DeNO $\mathrm{N}_{x}$ processes in diesel exhausts. VWT shows a good stability in sulfur oxide-rich combustion exhausts [5]. It has already been suggested as a sensor material for ammonia sensing purposes in exhausts [6-8].

To the best of our knowledge, there are only a few papers reporting on $\mathrm{SO}_{2}$ sensors utilizing $\mathrm{V}_{2} \mathrm{O}_{5} / \mathrm{TiO}_{2}$ (without $\mathrm{WO}_{3}$ ) $[9,10]$ and there is no paper that involves VWT as an $\mathrm{SO}_{2}$ sensitive material in potentialtype gas sensors, although there are many papers about $\mathrm{SO}_{2}$ oxidation of VWT in SCR catalysts [11-16]. Liang et al. reported on bulk-type potential or electromotive force-type (EMF) sensor using $\mathrm{V}_{2} \mathrm{O}_{5}-\mathrm{TiO}_{2}$ with Au electrodes and a Nasicon sodium ion conductor [9]. In contrast, in our study, we realized a planar setup for our EMF type sensors and utilized VWT with a $\mathrm{V}_{2} \mathrm{O}_{5}$ concentration of $1.5 \mathrm{wt} \%$ and $3.0 \mathrm{wt} \%$. We also varied the electrode materials between $\mathrm{Pt}$ or $\mathrm{Au}$ and measured the EMF changes when exposed to $\mathrm{SO}_{2}$ and/or other gases. Unexpectedly, it was found out that for the $\mathrm{SO}_{2}$ response the electrode materials play a more crucial role.

\section{EXPERIMENTAL}

VWT powders were supplied by a commercial catalyst supplier. The $\mathrm{V}_{2} \mathrm{O}_{5}$ concentration was 1.5 or 3.0 $\mathrm{wt} \%$ and the $\mathrm{WO}_{3}$ concentration was ca. $8-10 \mathrm{wt} \%$. In this study, $x \% \mathrm{VWT}$ is an abbreviation that stands for the composition $x \mathrm{wt} \% \mathrm{~V}_{2} \mathrm{O}_{5} / 8 \sim 10 \mathrm{wt} \% \mathrm{WO}_{3} / \mathrm{TiO}_{2}$, in which $x$ is 1.5 or 3.0. The VWT powders were 
added into an organic binder to prepare screen-printable pastes. Nasicon powder was also added into an organic binder to prepare screen-printable pastes.

First, a solid electrolyte layer (Nasicon) was screen-printed. Then, two porous gold electrodes were screen-printed. Afterwards, one electrode was covered by an additional porous catalytically active film (VWT) which included 1.5 or $3.0 \mathrm{wt} \% \mathrm{~V}_{2} \mathrm{O}_{5}$. The schematic setup of the sensor is given in Fig. 1. The cell can be described by:

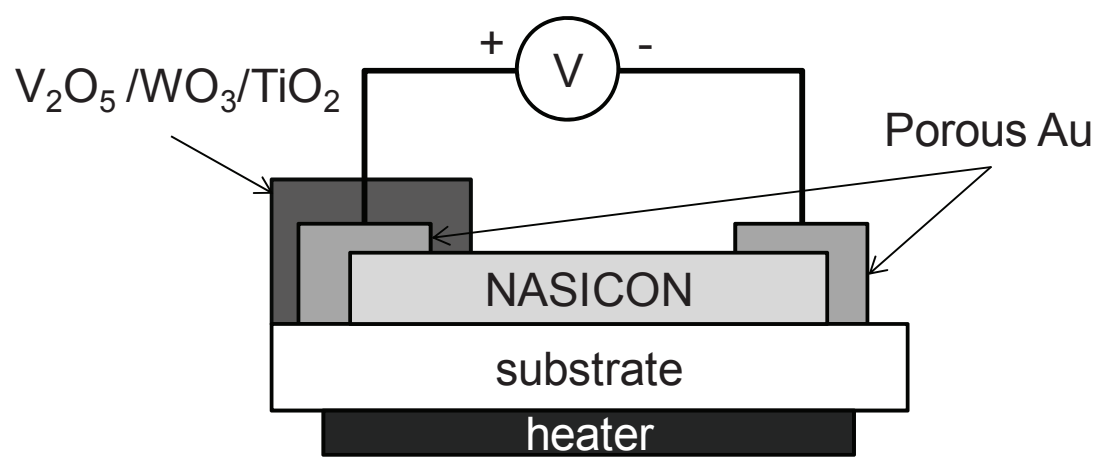

Figure 1. Schematic setup of the sensor.

To investigate its sensing properties, the sensor devices were placed into a test chamber with an angle of incidence parallel to the gas flow. The total gas flow amounted to either 1 or $5 \mathrm{~L} / \mathrm{min}$. The voltage between two gold or platinum electrodes was measured as an output of the sensor with a digital multimeter (Keithley 2700 series). As a base gas, compressed air was used to measure the response to $\mathrm{SO}_{2}$, while a gas mixture of $20 \% \mathrm{O}_{2}$ and $80 \% \mathrm{~N}_{2}$ was used in the case of the response measurement towards other gases like $\mathrm{CO}, \mathrm{CO}_{2}, \mathrm{C}_{3} \mathrm{H}_{8}, \mathrm{H}_{2} \mathrm{O}, \mathrm{H}_{2}, \mathrm{NO}$, and $\mathrm{NH}_{3}$.

\section{RESULTS AND DISCUSSION}

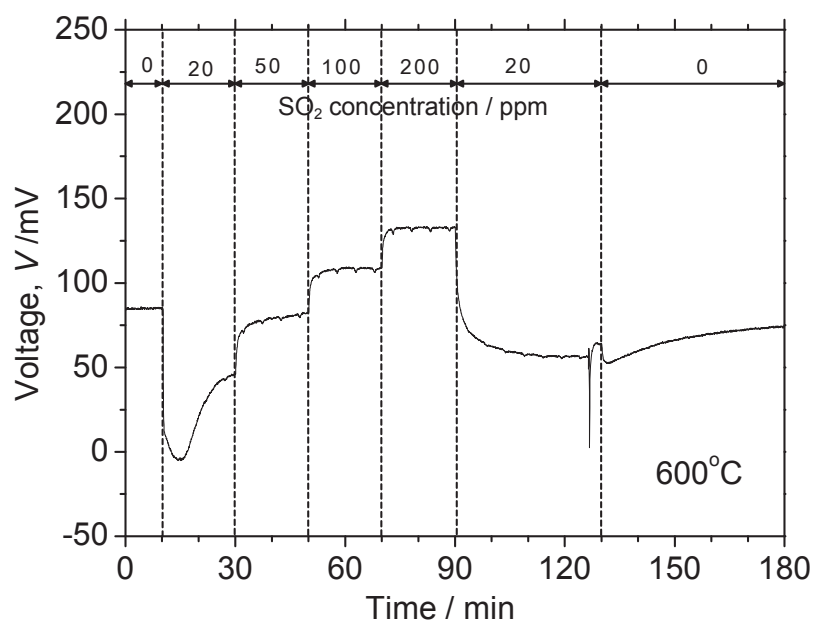

Figure 2. Response curve of the sensor using $3.0 \mathrm{wt} \% \mathrm{~V}_{2} \mathrm{O}_{5}$ at $600^{\circ} \mathrm{C}$

In the low temperature range $\left(300^{\circ} \mathrm{C}\right.$ to $\left.400{ }^{\circ} \mathrm{C}\right)$, the sensor shows a non-reproducible behavior, both in base gas and under $\mathrm{SO}_{2}$ exposition. At temperatures of $500^{\circ} \mathrm{C}$ or more, the voltage is stable and the 
voltage increased with increasing $\mathrm{SO}_{2}$ concentration in the $\mathrm{SO}_{2}$ range from 20 to $200 \mathrm{ppm}$ (Fig.2). The effect directly after admixing $20 \mathrm{ppm} \mathrm{SO}$ to the base gas has not been understood at the moment.

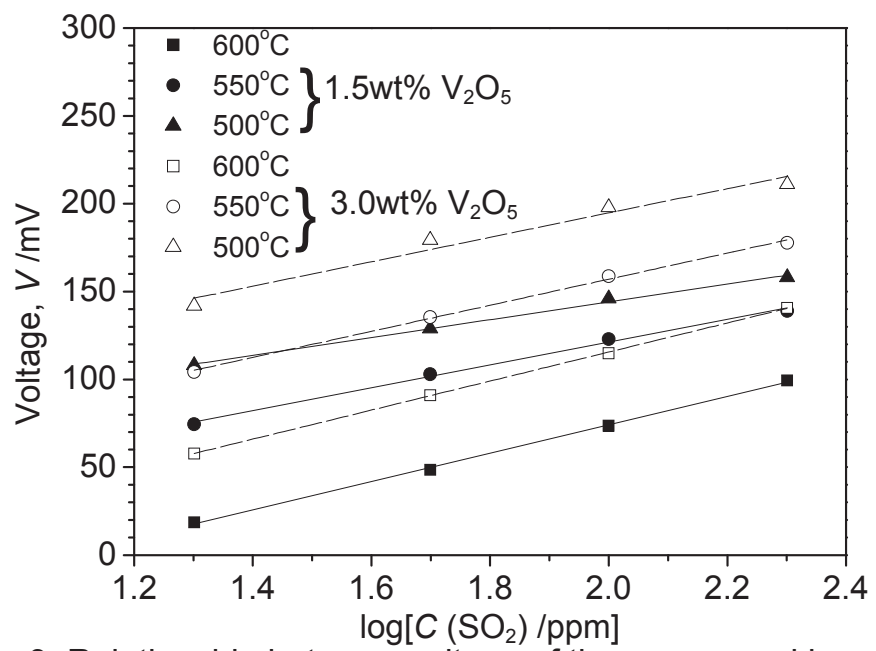

Figure 3. Relationship between voltage of the sensor and log of $\mathrm{SO}_{2}$ concentration $\left(\mathrm{C}\left(\mathrm{SO}_{2}\right)\right)$.

Figure 3 shows the relationship between the obtained sensor voltage and the logarithm of the $\mathrm{SO}_{2}$ concentration. The slope of the line in a semi-logarithmic plot increases with increasing temperature in the range from 20 to $200 \mathrm{ppm}$. The sensitivity of the sensor with $1.5,3.0 \mathrm{wt} \% \mathrm{~V}_{2} \mathrm{O}_{5}$ is $80-83 \mathrm{mV} /$ decade at $600{ }^{\circ} \mathrm{C}$. The slope of the sensors with $3.0 \mathrm{wt} \% \mathrm{~V}_{2} \mathrm{O}_{5}$ is higher than that of the sensors with $3.0 \mathrm{wt} \% \mathrm{~V}_{2} \mathrm{O}_{5}$ at each temperature. This sensitivity would be suitable for high temperature application.

The results are different to the bulk-type sample as reported in Ref. [9]. There, no information about the sensor response over $300{ }^{\circ} \mathrm{C}$ was given, and a stable response was observed at $300{ }^{\circ} \mathrm{C}$. When we repeated our measurements, an offset shift is observed but the slope remains almost the same. This problem may be related to the strange response when $\mathrm{SO}_{2}$ concentration changes from $0 \mathrm{ppm}$ to $20 \mathrm{ppm}$. In high $\mathrm{SO}_{2}$ concentrations ( $200 \mathrm{ppm}-5000 \mathrm{ppm}$ ), a decrease of the slope is observed. This means that a kind of saturation of the signal occurs at high $\mathrm{SO}_{2}$ concentrations.

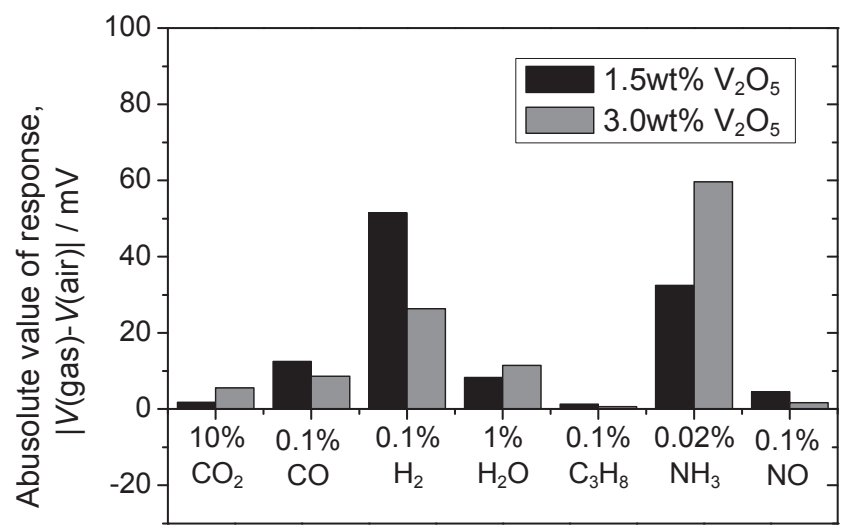

Figure 4. Response to various gases.

Figure 4 shows the results of the cross sensitivity tests. The sensors with $1.5 \mathrm{wt} \%$ and $3.0 \mathrm{wt} \% \mathrm{~V}_{2} \mathrm{O}_{5}$ show only little or no response to $\mathrm{CO}_{2}, \mathrm{CO}, \mathrm{H}_{2} \mathrm{O}, \mathrm{C}_{3} \mathrm{H}_{8}$ and $\mathrm{NO}$, and only $\mathrm{H}_{2}$ and $\mathrm{NH}_{3}$ lead to marked effects. It seems that the sensors may be selective enough for in-situ waste gas monitoring of coal combustion processes. However, the long-term signal stability needs to be further investigated. 


\section{Conclusions}

In this study, we manufactured a planar type sensor with Nasicon as an electrolyte and Au and $\mathrm{Au} / \mathrm{VWT}$ as electrodes. We investigated the response properties towards $\mathrm{SO}_{2}$ and towards many interfering gases. The results and conclusions obtained in this study are as follows:

1) In the low temperature range $\left(300^{\circ} \mathrm{C}-400^{\circ} \mathrm{C}\right)$, the sensor showed a non-reproducible response to $\mathrm{SO}_{2}$. At temperatures of $500{ }^{\circ} \mathrm{C}$ or more, the voltage is stable and the sensor output increases with increasing $\mathrm{SO}_{2}$ concentration in the $\mathrm{SO}_{2}$ range from 20 to $200 \mathrm{ppm}$.

2) The slope in a semi-logarithmic plot (voltage vs. log of $\mathrm{SO}_{2}$ concentration) increases with increasing temperature in the range from 20 to $200 \mathrm{ppm}$. The sensitivity of the sensor with $1.5,3.0 \mathrm{wt} \% \mathrm{~V}_{2} \mathrm{O}_{5}$ is $80-83 \mathrm{mV} /$ decade $\mathrm{SO}_{2}$ at $600{ }^{\circ} \mathrm{C}$.

3) In high $\mathrm{SO}_{2}$ concentrations (200 ppm - $5000 \mathrm{ppm}$ ), a saturation of the sensor signal in high $\mathrm{SO}_{2}$ concentrations is observed.

4) The sensors with $1.5 \mathrm{wt} \%$ and $3.0 \mathrm{wt} \% \mathrm{~V}_{2} \mathrm{O}_{5}$ showed little or no response to $\mathrm{CO}_{2}, \mathrm{CO}, \mathrm{H}_{2} \mathrm{O}, \mathrm{C}_{3} \mathrm{H}_{8}$ and NO. It seems that the sensors may be selective enough for in-situ waste gas monitoring of coal combustion processes. However, the long-term signal stability needs to be further investigated.

These investigations are a part of a series that studies how VWT can be used for $\mathrm{SO}_{2}$ sensing. Whereas at the moment the long-term stability of the potential-type sensors requires further improvements, conductometric sensors using VWT as the sensitive film perform better. They can be operated at $400{ }^{\circ} \mathrm{C}$. The resistance of VWT decreases with an increasing $\mathrm{SO}_{2}$ concentration in the range from $20 \mathrm{ppm}$ to 5000 $\mathrm{ppm}$. The sensor response is linear in a logarithmic scale, but no saturation effect occurs. The long-term stability is promising and the cross-sensitivity is similar to the one as found out in this work. Further details can be found in [17].

\section{References}

[1] C.A. Powell, B.D. Morreale, Materials challenges in advanced coal conversion technologies, MRS Bull. 33 (2008) 309-315.

[2] S.S. Bhoga, K. Singh, Electrochemical solid state gas sensors: An overview, lonics 13 (2007) 417427.

[3] G. Busca, L. Lietti, G. Ramis, F. Berti, Chemical and mechanistic aspects of the selective catalytic reduction of NOx by ammonia over oxide catalysts: A review, Appl. Catal. B 18 (1998) 1-36.

[4] P. Forzatti, Present status and perspectives in de-NOx SCR catalysis, Appl. Catal. A 222 (2001) 221236.

[5] M. Casanova, E. Rocchini, A. Trovarelli, K. Schermanz, I. Begsteiger, High-temperature stability of $\mathrm{V}_{2} \mathrm{O}_{5} / \mathrm{TiO}_{2}-\mathrm{WO}_{3}-\mathrm{SiO}_{2} \mathrm{SCR}$ catalysts modified with rare-earths, J. Alloys Compd. 408 (2006) 11081112.

[6] D. Schonauer, K. Wiesner, M. Fleischer, R. Moos, Selective mixed potential ammonia exhaust gas sensor, Sens. Actuators B 140 (2009) 585-590.

[7] D. Schonauer, T. Nieder, K. Wiesner, M. Fleischer, R. Moos, Investigation of the electrode effects in mixed potential type ammonia exhaust gas sensors, Solid State lonics (2010) doi:10.1016/j.ssi.2010.1003.1028.

[8] R. Moos, Catalysts as Sensors - A Promising Novel Approach in Automotive Exhaust Gas Aftertreatment, Sensors 10 (2010) 6783-6787.

[9] X.S. Liang, T.G. Zhong, B.F. Quan, B. Wang, H.S. Guan, Solid-state potentiometric $\mathrm{SO}_{2}$ sensor combining NASICON with $\mathrm{V}_{2} \mathrm{O}_{5}$-doped $\mathrm{TiO}_{2}$ electrode, Sens. Actuators B 134 (2008) 25-30.

[10]D. Morris, R.G. Egdell, Application of $\mathrm{V}$-doped $\mathrm{TiO}_{2}$ as a sensor for detection of $\mathrm{SO}_{2}$, J. Mater. Chem. 11 (2001) 3207-3210.

[11]F.Y. Chang, J.C. Chen, M.Y. Wey, S.A. Tsai, Effects of particulates, heavy metals and acid gas on the removals of $\mathrm{NO}$ and $\mathrm{PAHs}$ by $\mathrm{V}_{2} \mathrm{O}_{5}-\mathrm{WO}_{3}$ catalysts in waste incineration system, J. Hazard. Mater. 170 (2009) 239-246.

[12] P. Forzatti, I. Nova, A. Beretta, Catalytic properties in deNO(x) and $\mathrm{SO}_{2}-\mathrm{SO}_{3}$ reactions, Catal. Today 56 (2000) 431-441. 
[13] J.H. Goo, M.F. Irfan, S.D. Kim, S.C. Hong, Effects of $\mathrm{NO}_{2}$ and $\mathrm{SO}_{2}$ on selective catalytic reduction of nitrogen oxides by ammonia, Chemosphere 67 (2007) 718-723.

[14] H. Kamata, S. Ueno, T. Naito, A. Yukimura, Mercury Oxidation over the $\mathrm{V}_{2} \mathrm{O}_{5}\left(\mathrm{WO}_{3}\right) / \mathrm{TiO}_{2}$ Commercial SCR Catalyst, Ind. Eng. Chem. Res. 47 (2008) 8136-8141.

[15] M. Kobayashi, M. Hagi, $\mathrm{V}_{2} \mathrm{O}_{5}-\mathrm{WO}_{3} / \mathrm{TiO}_{2}-\mathrm{SiO}_{2}-\mathrm{SO}_{4}{ }^{2-}$ catalysts: Influence of active components and supports on activities in the selective catalytic reduction of $\mathrm{NO}$ by $\mathrm{NH}_{3}$ and in the oxidation of $\mathrm{SO}_{2}$, Appl. Catal. B 63 (2006) 104-113.

[16]Y.J. Zheng, A.D. Jensen, J.E. Johnsson, Deactivation of $\mathrm{V}_{2} \mathrm{O}_{5}-\mathrm{WO}_{3}-\mathrm{TiO}_{2} \mathrm{SCR}$ catalyst at a biomassfired combined heat and power plant, Appl. Catal. B 60 (2005) 253-264.

[17] N. Izu, G. Hagen, D. Schönauer, U. Röder-Roith, R. Moos, Application of $\mathrm{V}_{2} \mathrm{O}_{5} / \mathrm{WO}_{3} / \mathrm{TiO}_{2}$ for resistivetype $\mathrm{SO}_{2}$ sensors, accepted for publication in "Sensors" (2011). 